\title{
Recruitment Behavior During Foraging in the Neotropical Ant Gnamptogenys moelleri (Formicidae: Ponerinae): Does the Type of Food Matter?
}

\author{
Rodrigo Cogni ${ }^{1,2}$ and Paulo S. Oliveira ${ }^{2,3}$ \\ Accepted December 18, 2003; revised March 23, 2004
}

Gnamptogenys moelleri nests in bromeliads and feeds on an array of food items, including dead and live animals, and nectar. Field data in Brazilian forests indicate that $\mathrm{G}$. moelleri hunts solitarily, while retrieving is performed both by solitary workers for small items, or by a group of recruited workers for large items. This flexible foraging strategy was investigated in the laboratory through a series of experiments to assess the context in which recruitment is elicited. Three types of food were used: $50 \%$ honey solution, large insect prey, and cluster of small insects. For all food types the first encounter by a scout resulted in increased numbers of ants leaving the nest and finding the food in the arena. After finding liquid food or large prey, the forager returns to the nest and transmits information to nestmates about food location on the substrate. The successful scout repeatedly taps the sting on the ground, and recruited ants collectively retrieve the large insect to the nest. On the other hand, there is no transmission of information to nestmates about the location of small clumped prey, although the returning scout induces nestmates to leave the nest and hunt. Because foraging in $\mathrm{G}$. moelleri is restricted mostly to the nest bromeliad, and small worker size $(0.5 \mathrm{~cm})$ precludes capturing large prey solitarily, recruitment behavior widens the spectrum of food items consumed by this ant species. Although recruitment behavior in ponerines has already

\footnotetext{
${ }^{1}$ Department of Ecology and Evolutionary Biology, University of Michigan, Ann Arbor, Michigan.

2Departamento de Zoologia, C.P. 6109, Universidade Estadual de Campinas, 13083-970 Campinas SP, Brasil.

${ }^{3}$ To whom correspondence should be addressed. E-mail: pso@unicamp.br.
} 
been reported to vary with the type and size of a food source, this study also shows that the transmission of information about food location depends on the type of food found (large prey or liquid food versus cluster of small prey).

KEY WORDS: ants; communication; Ectatommini; foraging behavior; group retrieval; recruitment.

\section{INTRODUCTION}

Foraging mode may vary widely among ants, ranging from solitary hunting without any cooperation during search and food retrieval, to different levels of cooperative foraging mediated by different types of recruitment communication between nestmates (Carrol and Janzen, 1973; Traniello, 1989; Hölldobler and Wilson, 1990). The ability to recruit nestmates to profitable food sources is considered an important attribute leading to the ecological and evolutionary success of social insects (Wilson, 1971). Recruitment behavior during foraging activity occurs when a scout ant returns to the nest after having discovered a food source, and transmits information concerning food location to inactive foragers in the nest. There are three basic types of recruitment behavior during foraging in ants: (1) tandem running, in which the scout guides just one recruit to the food item; (2) group recruitment, in which the scout guides a group of ants to the food; and (3) mass recruitment, in which a trail laid by the recruiter while returning to the nest guides recruits to the food and these recruits can become recruiters in their turn (see Attygalle and Morgan, 1985; Beckers et al., 1989; Hölldobler and Wilson, 1990; Liefke et al., 2001). Foraging strategies among ants do not reflect phylogenetic relationships and probably result from unique selective pressures on each species (Hölldobler, 1984a; Baroni-Urbani, 1993). For instance, in the subfamily Ponerinae recruitment trail communication has evolved independently many times and five different trail pheromone glands have already been identified (Hölldobler and Wilson, 1990).

With almost 100 species described, Gnamptogenys ants are widespread in the Oriental, Indo-Australian, and Neotropical regions (Bolton, 1995; Lattke, 1995). This genus is phylogenetically close to Ectatomma and Rhytidoponera, belonging to the tribe Ectatommini, a derived taxon in the Ponerinae subfamily (Lattke, 1994; Keller, 2000). Most Gnamptogenys species are considered rare and cryptic, and very few had their behavior and ecology studied (Pratt, 1994; Gobin et al., 1998a, b, 2001; Blatrix and Jaisson, 2000; Giraud et al., 2000; Blatrix et al., 2002). Pratt (1994) has presented evidence that G. horni recruits nestmates to food sources in the laboratory. Gnamptogenys menadensis uses chemical trails during homing, and also recruits nestmates to dense clusters of prey (Gobin et al., 1998b; Johnson et al., 2003). In addition, 
esters from the Dufour's gland have been identified as a trail pheromone in the South American species G. striatula, but the ecological circumstances in which the trail is used have not been determined (Blatrix et al., 2002).

Gnamptogenys moelleri is a medium-sized (ca. $0.5 \mathrm{~cm}$ ) ant that occurs in Neotropical lowland forested areas (Lattke, 1995). The species nests in bromeliads, and forages almost exclusively on the nest plant (Cogni and Oliveira, 2004). Gnamptogenys moelleri uses a wide array of invertebrates in its diet, hunting for live prey and, most frequently, scavenging for dead animals. Workers also collect extrafloral nectar on foliage. Hunting is always performed by solitary workers, while retrieving is performed both by solitary workers for small food items, or by a group of recruited workers (3-12 ants) that collectively transport large food items. The probability of a worker to recruit nestmates increased with load weight in the field, and the number of workers carrying an item was positively correlated with its weight (Cogni and Oliveira, 2004).

This study investigates the recruitment behavior of G. moelleri when fed with different types of food. Five questions were addressed: (1) Is there an increase in the number of ants leaving the nest after a worker had encountered food? (2) Is there an increase in the number of ants encountering the food, after a worker had first encountered it? (3) Does the first worker encountering food transmit information about food location to nestmates? (4) Is the information about food location transmitted on the substrate? (5) Do these behavioral responses vary with the type of food? To answer these questions a series of controlled experiments were carried out in the laboratory.

\section{Captive Colonies, and General Experimental Procedures}

Six Gnamptogenys moelleri colonies were collected at the sandy plain forest ("restinga" forest) of the Parque Estadual da Ilha do Cardoso $\left(25^{\circ} 03^{\prime} \mathrm{S}\right.$; $47^{\circ} 53^{\prime} \mathrm{W}$ ), a 22,500-ha island located off the coast of São Paulo State, SE Brazil (Barros et al., 1991). Colonies were all queenright, nested in bromeliads, had plenty of brood (altogether over 30 eggs, larvae, and pupae), and contained 50-186 workers. The colonies were cultured at $23-26^{\circ} \mathrm{C}$ and diffusely illuminated from above during day hours. Each colony was housed in one glass tube (2.2-cm diameter $\times 15-\mathrm{cm}$ length) containing water trapped at the end behind a cotton plug. The glass tube was placed in a nest box $(40 \times 20 \mathrm{~cm})$ connected to a foraging arena $(40 \times 20 \mathrm{~cm})$ by a small bridge. The ants were fed three times a week with freshly killed Drosophila flies, Tenebrium larvae, cockroaches, diluted honey, and synthetic ant diet (Bhatkar and Whitcomb, 1970). Colonies were similarly motivated to forage prior to the experiments, and were starved for $24 \mathrm{~h}$ before trials. All experiments 
were carried out between 7:00 and 16:00 h, and were replicated in each of the six cultured colonies. Control and treatment manipulations were randomly assigned to each colony in all experiments. Control and experimental manipulations were separated by at least 4 days in each colony.

Three types of food were used in the experiments: (a) liquid food $-2 \mathrm{ml}$ of honey solution $(50 \%)$ on a plastic dish (3.5-cm diameter); (b) a large (ca. $3 \mathrm{~cm}$ ) freshly killed cockroach; and (c) a group of 20 freshly killed adult Drosophila flies $(1 \mathrm{~mm})$. Further methodological details will be given with the description of the individual experiments.

\section{EXPERIMENT 1}

\section{Methods}

This experiment aimed to determine if the encounter of food by a forager causes an increase in the number of ants that leave the nest and find the food in the arena $(50 \mathrm{~cm}$ from the nest entrance). After the first ant that had discovered food returned to the nest, the number of ants leaving the nest, and the number of ants finding the food were counted during 2-min intervals for $10 \mathrm{~min}$. Ant performance was tested with the three types of food described above. Control tests relative to each type of food consisted of placing in the arena: (a) a plastic dish without honey solution; (b) a piece of polystyrene $(3 \mathrm{~cm})$; and (c) 20 pieces of polystyrene (1-mm each). Results were compared with repeated-measure ANOVA after log transformation of data.

\section{RESULTS}

After the first forager had discovered food in the arena, both the number of ants leaving the nest and encountering the food greatly surpassed the controls, irrespective of the type of food (Fig. 1a-c).

Upon discovering the honey solution or the cockroach, the first forager inspected the food with the antenna and apparently tasted it. After this, the successful scout returned to the nest tapping the sting onto the substrate (Fig. 2). With the cockroach, however, before returning to the nest the forager tried unsuccessfully to retrieve the large prey by vigorously biting and pulling its legs. When the returning ant entered the nest, nestmates exhibited increased locomotory activity. As the successful scout left the nest and returned to the newly discovered food, it again tapped the sting onto the substrate. Subsequently, nestmates left the nest tapping the antenna on the substrate, and reached the food source. A few ants, however, returned to the nest without finding the food. In the cockroach experiment, the large 

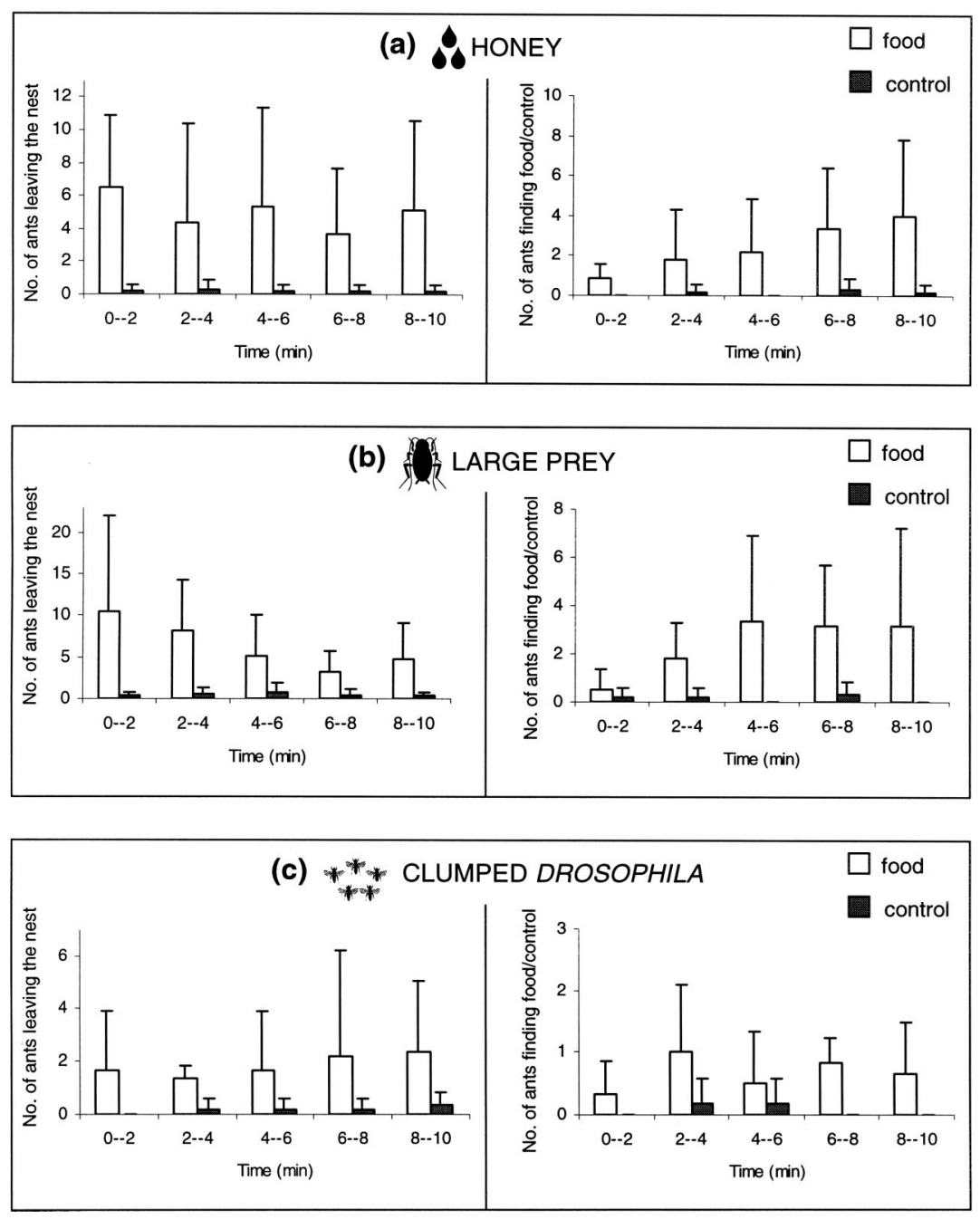

Fig. 1. Experiment 1. Number of Gnamptogenys moelleri workers leaving the nest (left) and finding food or control objects (right) in a foraging arena, during experiments using different types of food (honey, large cockroach, clumped Drosophila). Ant activity was recorded after the first ant that had discovered food or control objects returned to the nest. (a) dish with honey solution versus empty dish: leaving nest $(F=13.69 ; \mathrm{df}=1 ; P=0.004)$; finding food or control $(F=9.97$; $\mathrm{df}=1 ; P=0.001)$, (b) A $3 \mathrm{~cm}$ freshly killed cockroach versus $3-\mathrm{cm}$ piece of polystyrene: leaving nest $(F=7.94 ; \mathrm{df}=1 ; P=0.018)$; finding food or control $(F=7.38 ; \mathrm{df}=1 ; P=0.022)$, (c) cluster of 20 freshly killed Drosophila versus cluster of 20 small pieces of polystyrene: leaving nest $(F=9.97 ; \mathrm{df}=1 ; P=0.004)$; finding food or control $(F=21.40 ; \mathrm{df}=1 ; P=0.001)$. Values are means $+1 \mathrm{SE}(n=6$ colonies $)$. Repeated-measures ANOVA performed on log transformed data. 


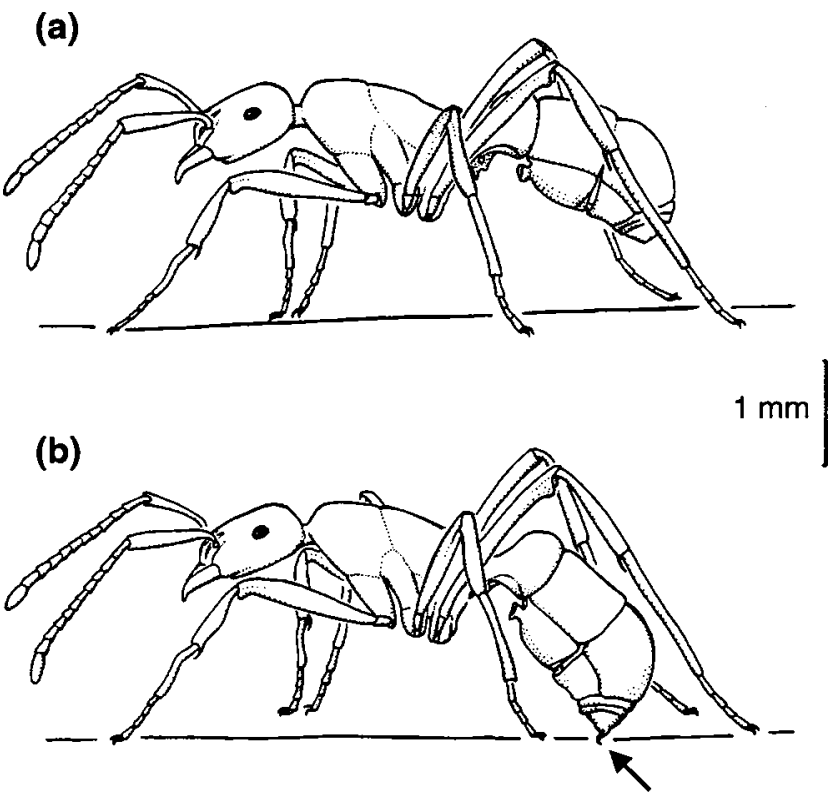

Fig. 2. (a) A Gnamptogenys moelleri forager walking in its normal position, (b) A forager tapping the sting onto the substrate (arrow) when returning to the nest after finding a large insect prey or honey solution.

prey was invariably carried to the nest by a group of ants. Ants behaved differently toward Drosophila prey. The first forager to find the flies stung one of them and carried it to the nest. However, the returning ant did not tap the sting onto the substrate. When the successful scout entered the nest some of the ants began to leave the nest and eventually found the flies. The original scout that had encountered the Drosophila returned repeatedly to the food source and retrieved up to eight flies in succession.

\section{EXPERIMENT 2}

\section{Methods}

To test whether the first forager to find food transmits information about food location to nestmates, the following experiment was carried out using each of the three types of food. Two cardboard bridges $(40 \times 3 \mathrm{~cm})$ connected the nest box to each of two separate locations (A and B) in the foraging arena. In the control observations the food was placed in location $\mathrm{A}$, while in location B no food was provided. After the first ant had discovered food, 
the number of ants walking over each bridge was recorded for $5 \mathrm{~min}$. In the experimental manipulations, food was placed in location A, and location B lacked a reward. After the first ant had encountered the food, the reward was transferred to location $\mathrm{B}$. The number of ants walking over each bridge was then recorded from 0 to $5 \mathrm{~min}$, and from 15 to $20 \mathrm{~min}$. The number of ants walking over each bridge was compared with a paired $t$ test.

\section{RESULTS}

In control tests, more ants walked over the bridge leading to the honey solution dish than over the bridge leading to the location deprived of food $(t=6.3 ; \mathrm{df}=5 ; P=0.001$; see Fig. 3a, HONEY). After the relocation of food following its discovery by a scout ant, more ants walked over the bridge leading to the previous food location (A) in the first 5 min than over the bridge leading to the current location (B) of the honey solution $(t=11.0$; $\mathrm{df}=5 ; P<0.001 ;$ Fig. 3b, HONEY). However, $15 \mathrm{~min}$ after food relocation ant traffic was higher over the bridge leading to the current food location (B) than over the bridge where honey solution was first encountered (location A) $(t=7.9$; df $=5, P=0.001$; Fig. 3c, HONEY). The same behavioral pattern was observed in the experiment using a large prey (cockroach) as food source (control: $t=6.5$; df $=5 ; P=0.001$; food relocation 0-5 min: $t=7.4 ; \mathrm{df}=5$; $P=0.001$; food relocation 15-20 $\min : t=7.7 ; \mathrm{df}=5 ; P=0.001$ ) (Fig. 3a-c, LARGE PREY).

Results from the experiment using Drosophila flies as food source differed markedly from the above pattern (Fig. 3a-c, CLUMPED DROSOPHILA). Ant traffic over the bridges was similar after the flies had been discovered by a forager at location $\mathrm{A}(t=2.0 ; \mathrm{df}=5 ; P=0.10)$. The pattern did not change after $5 \min (t=1.5, \mathrm{df}=5 ; P=0.20)$ or $15 \mathrm{~min}$ $(t=0.4 ; \mathrm{df}=5 ; P=0.69)$ after food relocation.

\section{EXPERIMENT 3}

\section{Methods}

The aim of this experiment was to determine if the information about food location is transmitted on the substrate. The same experimental set with the two bridges described above was used. The only food types used in this experiment were honey solution and cockroach, because experiment 2 showed that there is no information about food location when the food source is the cluster of Drosophila. The food was placed in location A, and after the first forager had encountered it and returned to the nest, the food was removed from the arena and the bridges were exchanged. The number 

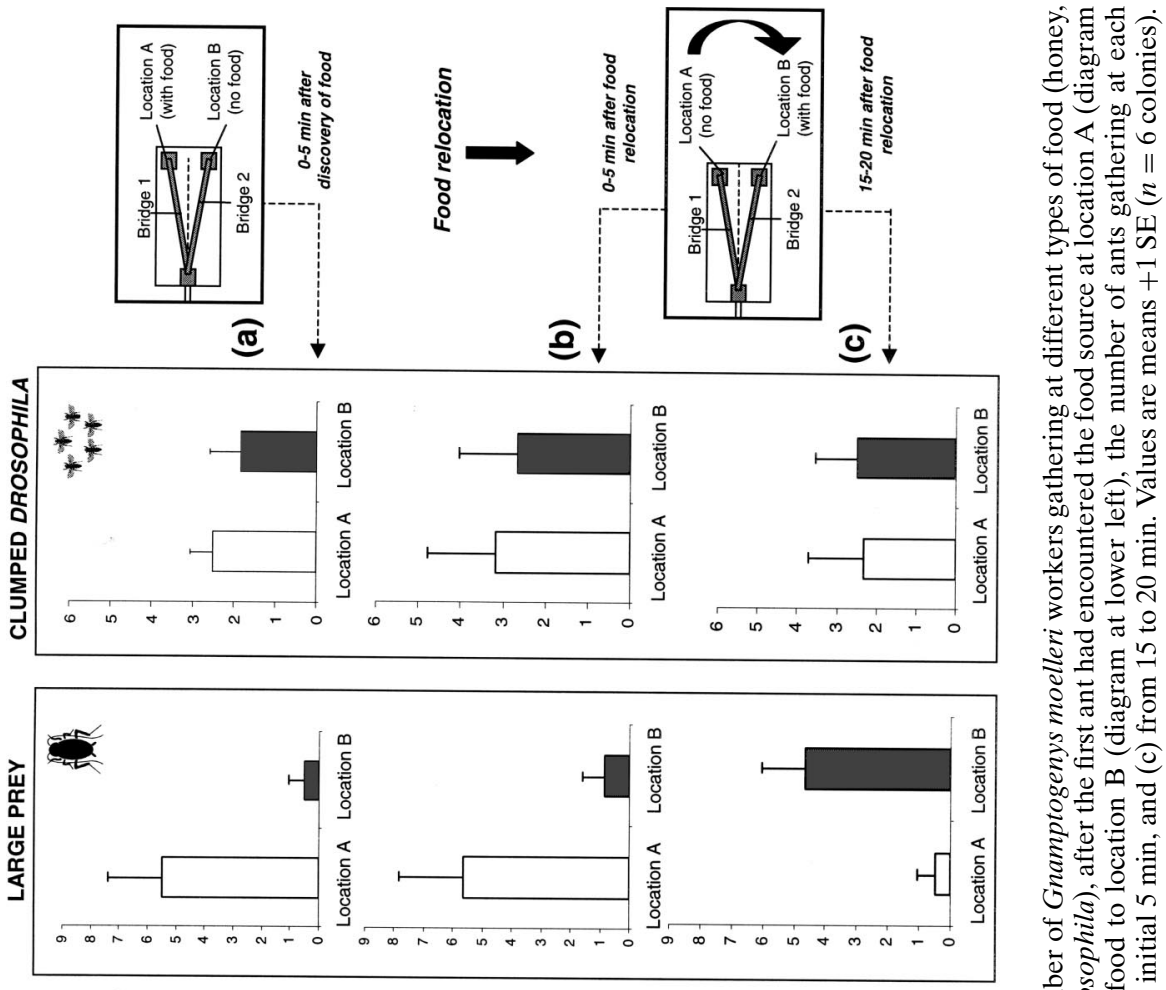

ㅇํㄹ

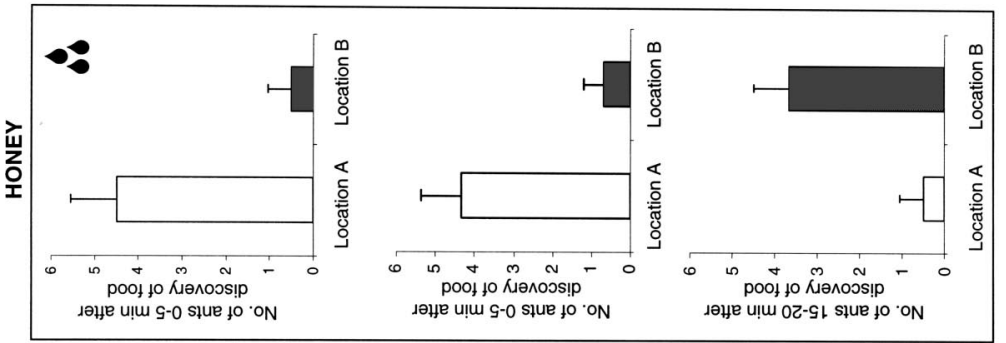

乙可

(ีత్రి

艺志志氖

ฮิ

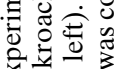

Iิ) ঠัญ

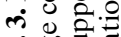
용 츠 흐으 
of ants reaching location A or B over 5 min was recorded and compared with paired $t$ tests.

\section{RESULTS}

After the bridges had been exchanged, the number of ants reaching location B (no food) was higher than the number of ants reaching location A (where food had been discovered prior the experimental manipulation). Results were significant using either a honey solution $(t=5.8$; $\mathrm{df}=5 ; P=$ $0.002)$ or a cockroach $(t=3.4 ; \mathrm{df}=5 ; P=0.02)$ as the food source (Fig. 4a,b).

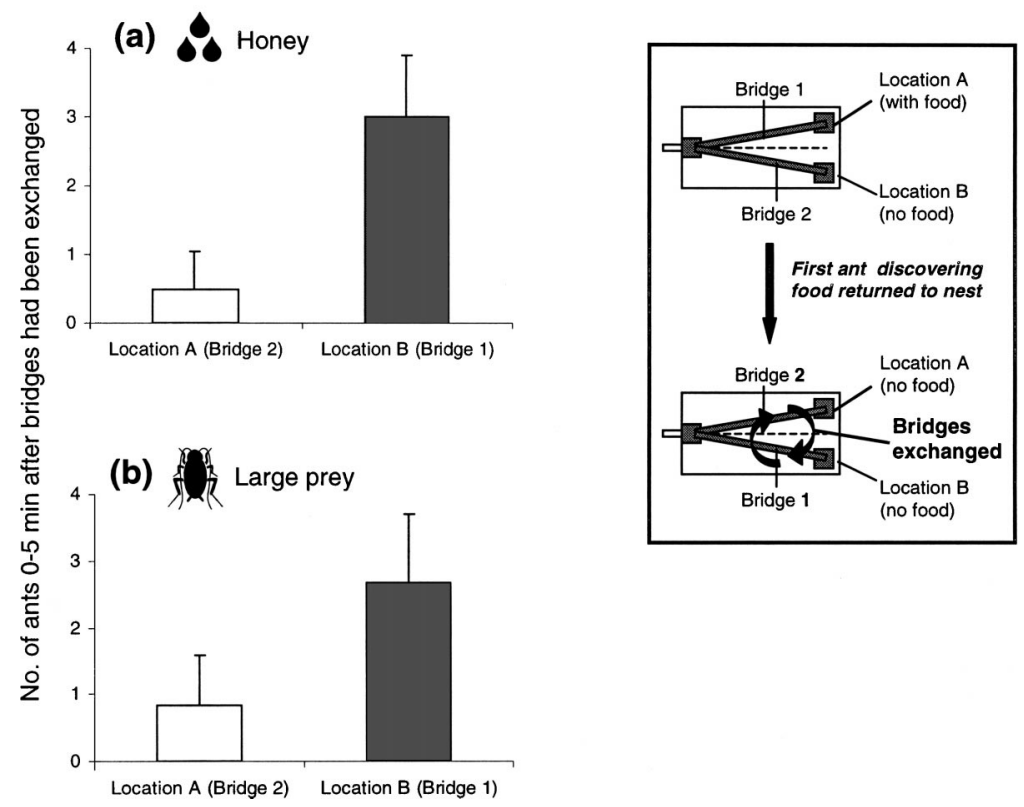

Fig. 4. Experiment 3. Number of Gnamptogenys moelleri workers gathering at a food source location. After the first ant had encountered food and returned to the nest, the two bridges were exchanged, and food was removed (see diagram at left). Data in (a) (honey solution) and (b) (cockroach) show ant traffic to either location over 5 min after the experimental manipulation. Values are means +1 SE $(n=6$ colonies $)$. 


\section{EXPERIMENT 4}

\section{Methods}

Our previous knowledge that scattered honeydew on the substrate can provide cues to ants (including Ectatommini) and increase ant attendance to a newly discovered food source (Del-Claro and Oliveira, 1996) led us to design an additional experiment to add to our initial study questions (and in particular to experiment 3). Because ants foraging on the honey often dampened their legs on the solution, this experiment was performed to test if the remains of honey on the substrate could provide information about food location to the ants. The same experimental set with two bridges was used. The honey solution was placed in location A, while location B received no food. After the first scout ant had encountered food and returned to the nest, the honey solution and the two bridges were removed. In control test, the bridges were replaced by two fresh ones. In the experimental manipulation the used bridges were each replaced by a fresh bridge leading to location A, and by a new bridge artificially damped with honey solution leading to location B. This bridge was daubed with a brush bristle damped in honey solution, simulating the ants' footsteps on the substrate. The number of ants reaching location A or B over 5 min was recorded and compared with paired $t$ tests.

\section{RESULTS}

The number of ants reaching each location was similar in the control situation $(t=0.35 ; \mathrm{df}=5 ; P=0.74 ;$ Fig. $5 \mathrm{a})$ as well as after the experimental manipulation $(t=0.34 ; \mathrm{df}=5 ; P=0.74$; Fig. $5 b)$.

\section{DISCUSSION}

The discovery of food by a G. moelleri forager resulted invariably in higher numbers of ants leaving the nest and finding the food source in the arena, irrespective of the type of food. Recruitment behavior in G. moelleri, however, does not necessarily contain information about food location. Further experimentation showed that when a forager encounters an aggregation of small prey, there is no transmission of information to nestmates about food location. In this case retrieval of food to the nest stimulates other ants to leave and, as a result, the number of ants finding the clustered prey also increases. This phenomenon ("social facilitation," see Wilson, 1971) is common in ponerine species such as Ophthalmopone berthoudi, Odontomachus 


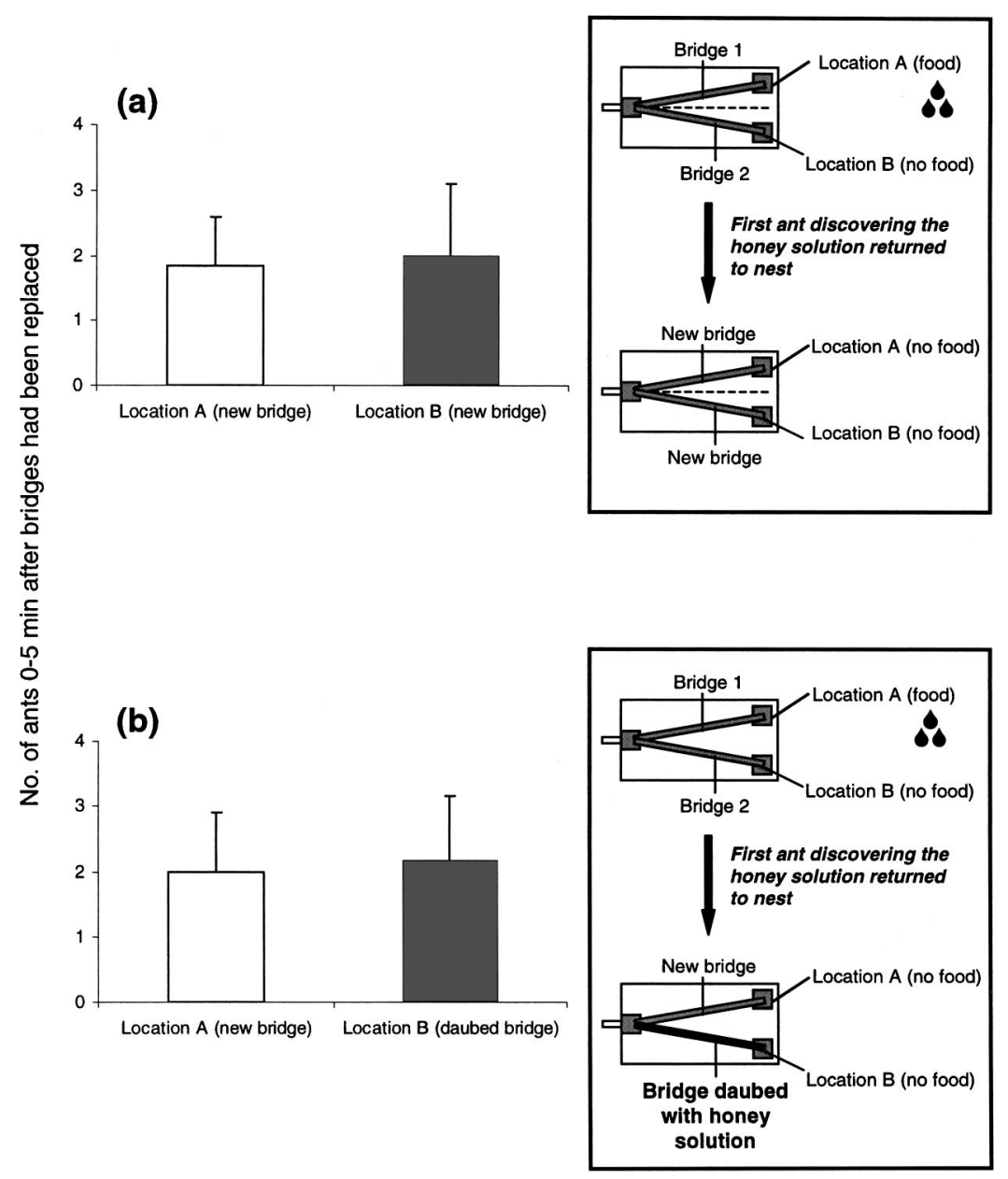

Fig. 5. Experiment 4. Number of Gnamptogenys moelleri workers gathering at honey solution at location A. After the first ant had encountered food and returned to the nest, the honey solution was removed and the two bridges were each (a) replaced by two new fresh bridges (diagram at upper left), (b) or replaced by a fresh bridge and a new bridge artificially daubed with honey solution (diagram at lower left). Data show intensity of ant traffic over the bridges during 5 min after the experimental manipulation. Values are means $+1 \mathrm{SE}(n=6$ colonies $)$. 
bauri, and Ectatomma permagnum (Peeters and Crewe, 1987; Oliveira and Hölldobler, 1989; Paiva and Brandão, 1989). In some species group retrieving of a food item can occur even without recruitment. This happens when a scout ant attracts nestmates in her immediate vicinity through the release of an alarm pheromone (Amblyopone pallipes, Traniello, 1982), a behavior clearly different from returning to the nest to recruit nestmates (Peeters and Crewe, 1987). When a G. moelleri forager finds liquid food or a large prey, it returns to the nest and transmits recruitment signals to nestmates that subsequently leave the nest. Additional directional information about food location is transmitted onto the substrate by the recruiting ant (possible glandular source is discussed below). In the case of the liquid food, our tests showed that remains of honey solution on the substrate provide no directional clue to ants about food location. Therefore the foraging strategy employed by $G$. moelleri is flexible, and depends on the kind of food encountered. Although employment of different recruitment systems depending on the type and size of a food source has already been reported in Paraponera and Ectatomma species (Overal, 1986; Breed et al., 1987; Schatz et al., 1997), this study extends our understanding of recruitment in ponerine ants by showing that the transmission of information about food location also depends on the type of food found (large prey or liquid food versus cluster of small prey). This flexibility permits colony adjustments to environmental changes in an adaptive way, and allows the utilization of alternate food sources by specialist species (Lachaud and Dejean, 1994), or the exploration of a wider range of food items by generalist species such as G. moelleri (Hölldobler, 1984b; Dejean et al., 1993).

Gnamptogenys moelleri has a limited spatial foraging range, which is restricted mostly to the leaves of the nest bromeliad (Cogni and Oliveira, 2004). Since the small size of G. moelleri workers (ca. $0.5 \mathrm{~cm}$ ) precludes single foragers from retrieving large prey, recruitment of nestmates widens the size range of food items available to the colony (Traniello, 1987; Cogni and Oliveira, 2004). Additionally, by recruiting nestmates G. moelleri may avoid losing the food to competitors (Cerdá et al., 1997; Johnson et al., 2003), which can occur in case of both large prey and liquid food (see Breed et al., 1987). Another advantage related with recruitment behavior in G. moelleri is the particular architecture of its foraging environment (see also Johnson et al., 2003). An ant species foraging exclusively on vegetation may have a high probability of encountering another forager on the return trip due to the limited number of primary branch routes leading to the nest. Indeed, Johnson et al. (2003) suggest that habitat architecture is the main factor shaping recruitment behavior in arboreal G. menadensis.

If G. moelleri is able to recruit and direct nestmates towards food sources, why is this not observed in the case of small clustered Drosophila? Field 
observations revealed that only $24 \%$ of food items are retrieved in a group by G. moelleri colonies, and this occurred for items larger than $7 \mathrm{~mm}$ (Cogni and Oliveira, 2004). Solitary G. moelleri foragers are able to retrieve small clustered insects by making successive trips, as also reported for Ectatomma quadridens (Overal, 1986). However, retrieving aggregate prey individually in several trips may take longer than retrieving in cooperation with recruited nestmates. This extra time could allow competitors to exploit the source, and ultimately result in the loss of the food. In fact other ant species such as Odontomachus hastatus, Dolichoderus attelaboides, Camponotus sp., and Crematogaster sp. also nest and forage in the same bromeliad species in which G. moelleri occurs (Cogni and Oliveira, 2004). Sequential individual retrieving may occur in G. moelleri because foragers may be unable to detect surplus prey in the immediate vicinity (persistent return to a profitable location by solitary foragers is well documented in ponerine ants, see Traniello, 1989; Fourcassié and Oliveira, 2002). In the laboratory, when approaching the aggregated Drosophila, the scout ant invariably stung and retrieved the first fly it seized, returning immediately to the nest, possibly without noticing the surplus prey nearby. Clusters of small prey may not be common in the field; in fact over $90 \%$ of the food items retrieved by G. moelleri were scavenged from dead invertebrates that in general are randomly distributed in the forest (Cogni and Oliveira, 2004). Johnson et al. (2003) have recently shown that G. menadensis has a recruitment strategy based on prey density, and recruits only to dense accumulations of termite prey, regardless of distance. However, unlike G. moelleri whose foraging range is limited primarily to the nest bromeliad (Cogni and Oliveira, 2004), colonies of G. menadensis maintain a high proportion of foragers out on branches, with intense traffic to/from the nest on primary branch trails which results in high encounter rates between recruits and nestmates near clumped termite prey (Johnson et al., 2003).

It is possible that directional recruitment information in G. moelleri is transmitted on the substrate by a trail pheromone produced by the Dufour's gland, as previously documented for the ponerines Ectatomma ruidum, Gnamptogenys menadensis, and G. striatula (Pratt, 1989; Bestmann et al., 1995; Gobin et al., 1998b; Blatrix et al., 2002), which are phylogenetically very close to G. moelleri (Lattke, 1994; Keller, 2000). Even though the gland secreting the trail pheromone has never been investigated in G. moelleri, the tapping of the sting onto the substrate (Fig. 2) is very similar to the behavior described in Ectatomma ruidum (Pratt, 1989). The use of Dufour's gland is rare among ponerine ants, since most species in this subfamily use secretion from poison or pygidial gland for trail communication (Hölldobler and Wilson, 1990). Even though different recruitment behaviors in ants are thought to have been convergently selected in different species by similar 
population/environment constraints (Baroni-Urbani, 1993), Dufour's gland in the Ectatommini may indicate a phylogenetic trend in glandular use.

Field studies have shown that G. moelleri has a generalized diet including mostly scavenged dead invertebrates, and more rarely live prey and nectar, and that the food items consumed vary greatly in size (Cogni and Oliveira, 2004). The present study shows that this flexible foraging strategy may allow G. moelleri colonies to consume a diversity of food items in the field. Recruitment decisions during foraging are closely linked with particular environmental factors that are relevant to the ants, including the foraging habitat (Detrain and Deneubourg, 2002). Our results, and the study of Johnson et al. (2003), on Gnamptogenys recruitment behavior indicate that comparative data under varying ecological contexts should further elucidate the links between dynamics of recruitment communication and the foraging environment.

\section{ACKNOWLEDGMENTS}

We thank the Instituto Florestal of São Paulo State and the Parque Estadual da Ilha do Cardoso for logistic support in the field. We are grateful to C. R. F. Brandão for help with ant identification. We also thank A. R. Moraes, H. P. Dutra, A. X. Linhares, K. Del-Claro, and A. V. L. Freitas for critical reading of the manuscript. Comments from two anonymous referees substantially improved the final version of the paper. Financial support was provided to R. C. by the Research Foundation of São Paulo (FAPESP) and to P. S. O. by the Brazilian Research Council (CNPq).

\section{REFERENCES}

Attygalle, A. B., and Morgan, E. D. (1985). Ant trail pheromones. Adv. Insect Physiol. 18: 1-30. Baroni-Urbani, C. (1993). The diversity and evolution of recruitment behavior in ants, with a discussion of the usefulness of parsimony criteria in the reconstruction of evolutionary histories. Insectes Soc. 40: 233-260.

Barros, F., Melo, M. M. R. F., Chiea, S. A. C., Kirizawa, M., Wanderley, M. G. L., and JungMendaçolli, S. L. (1991). Flora fanerogâmica da Ilha do Cardoso, 1, Instituto de Botânica, São Paulo, Brazil.

Beckers, R., Goss, S., Deneubourg, J. L., and Pasteels, J. M. (1989). Colony size, communication and ant foraging strategy. Psyche 96: 239-256.

Bestmann, H. J., Janssen, E., Kern, F., and Liepold, B. (1995). All-trans geranylgeranyl acetate and geranylgeraniol, recruitment pheromone components in the Dufour gland of the ponerine ant Ectatomma ruidum. Naturwissenschaften 82: 334-336.

Bhatkar, A., and Whitcomb, W. H. (1970). Artificial diet for rearing various species of ants. Fla. Entomol. 53: 229-232.

Blatrix, R., and Jaisson, P. (2000). Optional gamergates in the queenright ponerine ant Gnamptogenys striatula Mayr. Insectes Soc. 47: 193-197. 
Blatrix, R., Schulz, C. M., Jaisson, P., Francke, W., and Hefetz, A. (2002). Trail pheromone of ponerine ant Gnamptogenys striatula: 4-Methylgeranyl ester from Dufour's gland. J. Chem. Ecol. 28: $2557-2567$.

Bolton, B. (1995). A taxonomic and zoogeographical census of the extant ant taxa (Hymenoptera: Formicidae). J. Nat. Hist. 29: 1037-1056.

Breed, M. D., Fewell, J. H., Moore, A. J., and Williams, K. R. (1987). Graded recruitment in a ponerine ant. Behav. Ecol. Sociobiol. 20: 407-411.

Carroll, C. R., and Janzen, D. H. (1973). Ecology of foraging by ants. Annu. Rev. Ecol. Syst. 4: 231-257.

Cerdá, X., Retana, J., and Cros, S. (1997). Thermal disruption of transitive hierarchies in Mediterranean ant communities. J. Anim. Ecol. 66: 363-374.

Cogni, R., and Oliveira, P. S. (2004). Patterns in foraging and nesting ecology in the arboreal neotropical ponerine ant, Gnamptogenys moelleri. Insectes Soc. 51: 123-130.

Dejean, A., Lachaud, J. P., and Beugnon, G. (1993). Efficiency in the exploitation of patchy environments by the ponerine ant Paltothyreus tarsatus: an ecological consequence of the flexibility of prey capture behavior. J. Ethol. 11: 43-53.

Del-Claro, K., and Oliveira, P. S. (1996). Honeydew flicking by treehoppers provides cues to potential tending ants. Anim. Behav. 51: 1071-1075.

Detrain, C., and Deneubourg, J. L. (2002). Complexity of environment and parsimony of decision rules in insect societies. Biol. Bull. 202: 268-274.

Fourcassié, V., and Oliveira, P. S. (2002). Foraging ecology of the giant Amazonian ant Dinoponera gigantea (Hymenoptera, Formicidae, Ponerinae): Activity schedule, diet, and spatial foraging patterns. J. Nat. Hist. 36: 2211-2227.

Giraud, T., Blatrix, R., Poteaux, C., Solignac, M., and Jaisson, P. (2000). Population structure and mating biology of the polygynous ponerine ant Gnamptogenys striatula in Brazil. Mol. Ecol. 9: 1835-1841.

Gobin, B., Billen, J., and Peeters, B. C. (2001). Dominance interactions regulate worker mating in the polygynous ponerine ant Gnamptogenys menadensis. Ethology 107: 495508.

Gobin, B., Peeters, C., and Billen, J. (1998a). Colony reproduction and arboreal life in the ponerine ant Gnamptogenys menadensis (Hymenoptera: Formicidae). Neth. J. Zool. 48: 53-63.

Gobin, B., Peeters, C., Billen, J., and Morgan, E. D. (1998b). Interpecific trail following and commensalism between the ponerine ant Gnamptogenys menadensis and the formicine ant Polyrhachis rufipes. J. Insect Behav. 11: 361-369.

Hölldobler, B. (1984a). Evolution of insect communication. In Lewis, T. (ed), Insect Communication, Academic Press, London, pp. 349-377.

Hölldobler, B. (1984b). Communication during foraging and nest-relocation in the African stink ant, Paltothyreus tarsatus Fabr. (Hymenoptera, Formicidae, Ponerinae). Z. Tierpsychol. 65: 40-52.

Hölldobler, B., and Wilson E. O. (1990). The Ants, Harvard University Press, Cambridge, MA.

Johnson, C. A., Lommelen, E., Allard, D., and Gobin, B. (2003). The emergence of collective foraging in the arboreal Gnamptogenys menadensis (Hymenoptera: Formicidae). Naturwissenschaften 90: 332-336.

Keller, R. A. (2000). Cladistics of the tribe Ectatommini (Hymenoptera: Formicidae): A reappraisal. Insect Syst. Evol. 31: 59-69.

Lachaud, J. P., and Dejean, A. (1994). Predatory behavior of a seed-eating ant: Brachyponera senaarensis. Entomol. Exp. Appl. 72: 145-155.

Lattke, J. E. (1994). Phylogenetic relationships and classification of Ectatommine ants (Hymenoptera: Formicidae). Entomol. Scand. 25: 105-119.

Lattke, J. E. (1995). Revision of the ant genus Gnamptogenys in the New World (Hymenoptera: Formicidae). J. Hym. Res. 4: 137-193.

Liefke, C., Hölldobler, B., and Maschwitz, U. (2001). Recruitment behavior in the ant genus Polyrhachis (Hymenoptera, Formicidae). J. Insect Behav. 14: 637-657. 
Oliveira, P. S., and Hölldobler, B. (1989). Orientation and communication in the neotropical ant Odontomachus bauri Emery (Hymenoptera, Formicidae, Ponerinae). Ethology 83: 154166.

Overal, W. L. (1986). Recrutamento e divisão de trabalho em colônias naturais da formiga Ectatomma quadridens (Fabr.) (Hymenoptera: Formicidae: Ponerinae). Bol. Mus. Para. Emilio Goeldi Zoologia 2: 113-135.

Paiva, R. V. S., and Brandão, C. R. F. (1989). Estudos sobre a organização social de Ectatomma permagnum Forel, 1908 (Hymenoptera: Formicidae). Rev. Bras. Biol. 49: 783-792.

Peeters, B. C., and Crewe, R. (1987). Foraging and recruitment in ponerine ants: Solitary hunting in the queenless Ophthalmopone berthoudi (Hymenoptera: Formicidae). Psyche 94: 201214.

Pratt, S. C. (1989). Recruitment and other communication behavior in the ponerine ant Ectatomma ruidum. Ethology 81: 313-331.

Pratt, S. C. (1994). Ecology and behavior of Gnamptogenys horni (Formicidae: Ponerine). Insectes Soc. 41: 255-262.

Schatz, B., Lachaud, J. P., and Beugnon, G. (1997). Graded recruitment and hunting strategies linked to prey weight and size in the ponerine ant Ectatomma ruidum. Behav. Ecol. Sociobiol. 40: 337-349.

Traniello, J. F. A. (1982). Population structure and social organization in the primitive ant Amblyopone pallipes (Hymenoptera: Formicidae). Psyche 89: 65-80.

Traniello, J. F. A. (1987). Comparative foraging ecology of north temperate ants: The role of worker size and cooperative foraging in prey selection. Insectes Soc. 34: 118-130.

Traniello, J. F. A. (1989) Foraging strategies of ants. Annu. Rev. Entomol. 34: 191-210.

Wilson, E. O. (1971). The Insect Societies, Harvard University Press, Cambridge, MA. 